\title{
Scaffolding multilingualism in kindergarten children: A case study
}

\author{
Laxman KC \\ Lecturer, Mangal Multiple Campus Kirtipur, Kathmandu \\ Principal, Himchuli E.S. School Mahalaxmi-1, Lalitpur
}

\begin{abstract}
This qualitative case study research entitled 'Scaffolding multilingualism in kindergarten children: A case study' explored how kindergarten children face learning and communication barriers when they have different home language which is not the language of instruction at school and language of others at school. In addition, it revealed how kindergarten children's language identity and cognitive investment are not allowed by the monolingually biased pedagogical approach. It has presented the scenario of scaffolding monolingual children to multilingual basing their home language as the founding scaffold ingredients. A newly admitted kindergarten girl in pre-kindergarten school was the main source of the case study including her mother and her teacher for supporting information. Interviews and notes of observation and informal communication were the research tools used for data collection. Multilingual development of the home monolingual child is the thematic issue of this study.
\end{abstract}

Keywords: home language, communication barriers, translanguaging, multimodal semiotics, multilingualism

\section{Introduction}

Language has multiple facets in education. Language both facilitates and hinders in learning ranging from elementary to tertiary education. There are many issues: mother tongue education, second language acquisition, target language education, monolingual education, and bilingual education, multilingual education on language teaching and education regarding language policy in education. The language policy in education is influenced and agented by many agencies. Parents want their children to learn their own mother tongue for communication with their grandparents and want multilingualism for communication fluently in diverse communication situation (Markowska-Manista, Zakrzewska-Olędzka, \& Sawicki 2020). These issues are more or less ideologically bounded and influenced by power structure (Fairclough, 1989). Society and schools are interlinked entities whereas changes in one dimension reflect on another dimension. Schools may have the role of promotion of society by taking sources and information from the society and returning products back to society. There are many natural customs and practices 
in the society regarding language and its use (Kramsch, 2014). If such practices are incorporated in school education as language policy in education, it creates ownership and ensures identity (Norton, 2015) in learners and educators as a natural and living process but not as an extra burdening matter.

Naturally, human beings are social creatures, and technology and other dimensions of development have created the world as a global village (McLuhan, 1962) where languages and cultures are being localized and globalized simultaneously. Because of globalization, many monolingual and monoculture traditional societies in the various sections of the globe are being reconstructed and rebuilt scaffold. Its direct reflection is also realized in education and language in education. Even traditional monolingual societies are getting bilingualism and multilingualism. These situations germinate the need of multilingual education basically in school education.

Nepal is a multilingual country recognized by the state's main law (The Constitution of Nepal, 2015, Article 3) not only in terms of number of languages but also in terms of sociolinguistic practices by the speaker naturally in the community where they naturally reside. English as an international language, to some extent ideological, is the compatible entity in education in Nepal. Nepalese children, in urban areas like in Kathmandu valley are more or less natural multilingual (Kandel, 2019) because their parents, society and schools are both natural and learned multilingual. In the context of Nepal every child who joins the formal education is at least bilingual and many children who speak first other languages than Nepali are multilingual because they repertoire at least three languages namely their home language, and English and Nepali as their language of instruction at school. This situation has been created by many-monolingual educational policies. At least two language subjects English and Nepali are compulsory in all the schools except some students who are abroad. For many students both Nepali and English in their elementary schools are not their home languages in some rural areas where monolingual ethnic community people reside. But in their secondary levels, gradually they find Nepali as a lingua franca (Yadava, 2007) at school and home even there are others within the national territory.

Government language policy regarding education is monolingual (Education Act, 1971; Cummins, 2017). Societies and schools are multilingual but materials and pedagogies are monolingual. I as a teacher was educated through monolingual pedagogy and contents, and used to teach English with the monolingual approach. Children at school used to speak using multilingual repertoire but I used to impose 
them speak only language for better English learning. This makes them suppress their own language and cognitive property (Kioko, Ndungu, Njoroge, \& Mutiga, 2014) contained in their own language development for the sake of learning English language better. This is the worldwide hegemony of the English language. During new special admission period especially new schooling children at Saraswati Puja (child first schooling ceremony in accordance with Hindu practice), many new children were enrolled in the school where I used to teach with various language and cultural backgrounds. Out of many challenges for both teachers and children, one was language because the children who, from the ethnic language community or from different home language community, are new for both language and school. Learner as a social being negotiates historically constructed relationship between learner and the target language (Darvin \& Norton, 2017). Even if the children do not have the sufficient development of one or more of their home language/s, they are supposed to expose school language. There were three categories of children namely children with a home language that is not Nepali, children with home language Nepali and children with bilingual of Nepali and any other one ethnic language, e.g. Newari, Tamang, Maithili, Bhojpuri and so on. The children were supposed to expose English that is none of their home language. The children who are from Nepali home language or bilingual at least including Nepali face minimum communication barrier but the children who are monolingual with any one ethnic language face maximum communication barrier. Children cannot become automatically bilingual under institutional circumstances but need a carefully elaborated educational programme (Kitzinger, 2015).

One day a daughter child from Maithili home language background was severely weeping for long and a teacher and a helping staff tried to persuade her but it did not work. They thought that she was weeping because she was new and looking for her mother. Sometimes I used to go there and enjoyed playing with new children. Similarly, that day I reached there and observed. The teacher (miss) and the sister reported me that she had been weeping for long. I took her on my hand and out of the class. She was tired of long weeping. One remarkable matter for me with her was she was uttering some words with dubbed voice but they were not clear. I noticed the words the 'mutki aara' (it was in Maithili means I want to urinate) then I called one secondary level English teacher who was from Maithili home language community. I asked her what she was saying. Finally, she (the secondary teacher) was able to explore what the daughter child said. Then I was stroked how children face communication barriers in their multilingual initiation in schools, how natural and artificial multilingualism is developed in kids at school. 


\section{Methods and Procedures}

With the observation of the situation, I intended to study deep on the case as the qualitative researchers attempt to understand and interpret the meaning that is applied to a situation (Merriam, 2009). For this I designed qualitative case study. This qualitative research guided me in generating meaning and making sense of the meaning inductively from the collected data (Creswell, 2009). I intended to explore how teachers and parents contribute to develop multilingual child interacting the school and home language surrounding and deeper issues context in small groups (Hamilton \& Corbett-Whiter, 2013; Litosseliti, 2003 cited in Ping TAN, 2015). I selected Khusbu Thakur (anonymous), "children are pure witness without agendas, political opinions, and defined images to defend" (Kozol, 2005; cited in Lefebvre, 2012, p. 32) from first kindergarten, her teacher Muna Lama (anonymous) and her mother Radhadevi Thakur (anonymous). They were the people who could be congruent with the purpose of the study (Dornyei, 2007). The small number of participants facilitated me to collect deep level data from them interviewing the teacher and the parent especially observing with the child (Yin, 2014).

I devised unstructured short interviews time and again with both the teacher and the parent for five to 10 minutes, and frequent observation. I first called her (the parent) in the office and said that her child had language problem to communicate her ideas to teachers and understanding her teacher's instruction. Then I requested her to allow me study about her language learning as a multilingual learner. She was ready for it in advance to the child's better language learning support. Then I used to keeping note with observation of both the teacher and student as sometimes participant (Lodico, Spaulding \& Voegtle, 2010) and sometimes non-participant observer in their natural classroom. Sometimes I used to play and talk with low communication mutuality.

I went through the translanguaging process (Garcia \& Wei, 2018) of the child how the child is investing knowledge with home language and, how teacher, parent and the child are scaffolding multilingual languaging. Mostly children use pivotal sentence structure in their interactions as the due natural process of language development (Koegel, Koegel \& Carter, 1998). Even the single word of them functions as a sentence. Mothers are language recasting agencies even if it is criticized (Matthew, 2005) and understand better child communicative functions including various communicative semiotics. Children at school and at home have the specific language semiotics which are only familiar to mother and their children 
(Bedore, Pena, Joyner \& Macken 2011). I focused on child's languaging reference to use vocabulary, sentence and communicative competence at home and school scaffolding with teacher and parents. I duly consider the ethical matter and got permission from the mother using the anonymous respondents to prepare a research article on the case study and let it be published. I have not shared and will not share their real names.

\section{Result}

Since it is a case study, I have collected data from three concerning of the case. I was convinced that mother, the child and the teacher are reliable sources of data to reach in the case to conclude the exploration. When I found the child weeping severely for long and uttering some words which were eligible neither for the grade teacher nor for sisters who are close the children in school, I was struck with the issues and intended to have further studies. I speculated her problem because of language including others as being a new child at school feeling lonely, having no peer for mutual communication in her home language. Then I designed the case study on her including her mother and grade teacher and it was resulted as follow.

\section{Background scenario}

The Saraswati Puja is a Hindu practice of introducing new children to school or special virtue/holy day to start writing called writing beginning day (Akshararambha divash/ Basanta Panchami/ Saraswati Puja). It is believed in Hindu practices and Hindu Vedic education system that Saraswati is the Goddess (Devee) of education. The belief is that anyone who respects and have the faith to Devee Saraswati, can receive bless, protection and proper guidance for education. Even modern educated people have the respect to Devee Saraswati. It is much practised in Terai and Hill, and lightly in mountain area of Nepal. The Hindu and the Buddhist have the common belief on but they name it differently. In Swayambhu Nath Kathmandu, the Hindu people worship as Saraswati and the Buddhist as Manjushree the legendary figure for the betterment and blessing on education. It is rampant practice in Nepal. It is practised not only as the day of education initiation but also as the day of worshiping and collecting the blessing from the Devee Saraswati in schools and tertiary education in Nepal. This practice is being blurred in public schools. Generally, public schools remain close on the day and children visit different Saraswati Temples nearby and worship. In contrary, the institutional private and trust/ charity schools observe it as a great festival to celebrate, admit new students and visit parents. They publish and offer different financial offerings that lure parents to get admission for their children especially new comers. This is especially for this very day. 
During this occasion in Mount Range English Secondary School (anonymous), many new children were admitted to the pre kindergarten (Nursery) from various cultural and home language backgrounds. Some of them were of very young age ranging from one and half to three years old. At the beginning of some days or weeks, it is very difficult to adjust them to the school environment. Some of the children were not mentally, physically and psychologically ready to be educated because they did not have basic even home language development but they were supposed to educate in English. As I have lived experience, some of the parents who reside in rent in Kathmandu valley get admitted their children because they have to go for jobs and they have no people to care after their children at home. This makes them admit their children as early as possible. It ensures the best socialization process of urban children. Gradually they learn receiving and sharing ideas mutually in more than two languages as the multilingual children. They also use various semiotics of communication as the product of communication situational pressure. With the variation of children's cultural and home language environment, the variations in children learning difficulties and teacher's pedagogical implication difficulties seem common phenomena. This issue is barely noticed by the school administration, parents and even monolingually biased educated teachera.

\section{First day I noticed the child's language issue}

It was the last week of February 2018. One day I was observing various activities like children playing, teachers' classes, and activities of other staff and so on as my usual activities. Suddenly I found a new daughter child in Nursery weeping severely and it was prolonged weeping when I reached to Nursery class as my third visit of that class. The children were being prepared to send back home although it was about one hour left. Instead of trying to persuade and seek the problem of the child of what makes her weep, the teacher and sister ignored it. It was about a month of her school admission so seeking for her mother might not be the sole reason of weeping. It was my question in mind then I asked the teacher and the sister "Why is she weeping? Did you try to persuade?" The teacher responded, "Sir, I tried to convince her, I made her play but sometimes she weeps in the way we cannot stop her, she will stop when her mom comes." It means the teacher tried simple but it did not work, and then she left the issues. She (the teacher) did not identify the real problem that is why she could not help the child. Similarly, I asked the sister because they are very much familiar with child's various matters like language, interest, behaviour, convincing them and so on "Sister, why is Khusbu weeping?" Then she 
(the sister) responded the very serious issue, pointing to the child even if she was very much busy in managerial activities immediately after the school break time "Sir, she said something in her own language I could not understand her". And she (the sister) smiled and said additionally "Sir, she said 'mutki aara' or something like but what it is I don't know."

From these anecdotes, my hypothetical question about her weeping was near to conformation. However, it sought further investigation. I was able to notice that the child wanted to do something but it was not addressed by the respective persons. Neither the teacher and the sister nor her other peers helped her because they had not understood her home language that she used there and the girl was unable to convey her message in school language or the language that was mutually understood by others around her at school. Since she was not able to communicate to others, she might have been fleeing lonely even if there was crowd. It is the situation that people without communication they are like statue because she cannot share her space. She was not recognized, given identity and allowed her cognitive investment. She was as if she had joined the school with no knowledge and the school would plant the first seed of knowledge. The teacher and the sister did not try to understand her language. They only tried to use Nepali and English recasting words like "Good morning, bye, see you, good, naughty girl/boy, good girl/boy, clap etc."

I also asked her in Nepali "Why do you weep? Do you want to go to your mummy? Do I call your mummy?" but there was no change in her weeping. I immediately made a sister call a madam (TS hereafter) teaching in the senior class and belonging to the child language Maithili community. She (TS) came and asked in recasting tone her in Maithili the child home language "kathile kaanaichhi betuwa? (Why do you weep?), mummy kat jaicchi? (Do you want to go to your mummy?)" But the child said na (no). She again repeated the words or like sentence in very poorly audible voice "mutki jaichhi (I want to urinate)". Then TS questioned in rising tone "Mutki jaichhi? (Do you want to urinate?)". The girl answered yes through her facial expression and gesture. Then TS laughed openly and loudly. She (TS) said in Nepali " Sister, uoo suoo garni vanchha, garaidinus (sister, she wants to urinate, help and let her do)". I surprised on the situation how language creates communication barriers to the children who do not have their home language at school. After the action as sister did right after instruction TS gave, the child became calm.

About a half hour later, her mummy came to school gate to receive her daughter child. As I had already instructed the sister, she called her to me with her child. I reported all the events happened at school about two hours ago. I said her 
(mother) "It is being about a month of your child to be here even if she is not very regular. She cannot understand any language here we use at school. Don't you speak Nepali at home?" Then she responded, "Yes sir, sometimes we have to go to other places for our private job then she is irregular but we have managed all now she will be regular. She speaks well at home. We are here only couple so we use Maithili almost all time". That might be the reason she did not understand any language except some other gestures and miming semiotics at school. She is irregular so she did not catch up school language properly. While we (mother and me) were talking, she (mother) looked at her and asked in Maithili "Tuhe kanai chhi? Mutki lagal chhi? (Why did you weep? For urinating? )" The child did not respond verbally but facially she said yes. I requested her (mother) that I would study her behaviour and language development about a month. Then she agreed on it. She went out from the office and followed them she instructed her daughter in Maithili "bye bye kah di mam ke, bye bye kah di sir ke (say bye bye to madam, say bye bye to sir)". She (the child) smiled beautifully and said "bye bye" with her hand and facial expression but not with verbal expression. It means she had learned to say bye while leaving the people or school. From the very communication with mother and the responses made by the daughter child using various semiotics and symbols, we can infer that she was able to receive few other language chunks but not able to produce them and she was not able to make others understand her home language because her teachers and others did not make her leaning scaffold at school founding from her home language.

\section{On the following days}

The next day she (mother) came inside the school with her daughter. I called her class teacher and had a short interaction about the child and her language problem. I took her consent to observe her class formally at least ten times and I would have few unstructured interview with her. As I planned, I did the action. On the second day, the child had recognized me as a close person because I had already given her a chocolate. I and the teacher greeted her good morning. She only looked at us with curiosity. Then the mother said "Good morning kaha di sir mam ke (say good morning to sir and madam)". The child hardly in low pitch with childish manner said "Good morning."

\section{The child in class}

From the second day, the child's behaviours got changed gradually. Even if she had language problem to make others understand her ideas in her home language and responding to her peers and teacher verbally in school language, she was able to 
receive to school language few words because she could respond using other mode of communication rather than verbal as in language development process here as multilingual development. She looked quite fresh and happy that day. She moved here and there, played with friends, went to nearby teacher and used to sit. The teacher said in English with miming and gesture "Khubu, come here, your copy". The girl did the activities as the teacher instructed. Here it means she learned some English and Nepali words, phrases and pivotal sentences to receive but she could not produce and reproduce because her teacher did not make the scaffold of her home language, which could involve her in interaction to redesign her language repertoire. The teacher was not able to let her invest her cognitive property. From that day she was different as if she, her language and her identity, were recognized by the teacher and others at school. She felt belonging to others which could be inferred from her changing behaviours.

She was attended by the teacher and sisters, so she did not have the problem for that day and she did not weep. She played happily with others and she was happy when her mother came to receive her at late afternoon. On the following days, she got changed in her learning and appearing behaviour. I found her learning was in progress with translanguaging but she was still using other semiotics, facial expression, movement of head, eye contact, and hand gestures and so on to express her ideas. She could speak something using multilingual repertoire as her mother use with her "Good morning kaha di sir ke". But this level of multilingual awareness was not with the teacher so she did not try to explore her (the child) problem, instead she only avoided and imposed the monolingually biased approach.

\section{The teacher}

Initially the teacher rejected everything "Sir, I did everything but she does not speak anything. I told her mother too but she said she spoke at home". Of course, she might have done as she had the knowledge but she could not identify the problem related to language. Finally, she also realized that the girl made lonely behaviours because of communication barriers due to gap between school and home languages. On the following days when I visited her class, the teacher was more sensitive of the child and happy with her changing behaviours. She said, "Sir, she is very clever and active now. She helps others. She reports other's urinating problem, but language is still not clear, still uses home language and sometimes others seniors laugh at her". Improvements were there whatever the rate and route does not matter. Gradually the 
teacher was being her learning friend. Her home language was being reshaped with other additional languages English and Nepali semiotics. She had started matching English alphabet and figures representing to the alphabet learned with audiovisual drill practices.

\section{The mother}

After the first meeting, I met and made unstructured interview three times at the beginning, in the middle and at the end. Immediately after the first meeting, she was happy with us. She found the changes in her daughter so she was interested in visiting me. Many times, she wanted to see me because of my rush hour I could not manage time to her. In the second meeting, she said to me:

"Thank you sir, uoo ahile nikai chlakha vayechha, tapaile nai garda yeto vayera aayechh (Thank you sir, she is very good/clever now, she is being different because of you)".

She was very much cooperative and informative. I felt that I was being able to channelize the child's learning as a multilingual learner. Our group effort was making the reshaping of her language.

I asked her "Talk to your child at home while you both husband and wife talking to each other. Ask your daughter what she did at school, her teacher and her peers. These all will make your daughter an active learner".

In the final meeting, she shared that her husband was also happy and he wanted us. She shared other various activities she did at home with her daughter.

\section{Discussion}

Children are how we carve and shape them. If we go through learners' perspective, we can change them as we desire but if we impose our perspective then neither do they remain themselves nor our own. They are puzzled in their learning and become counterproductive. Many children get frustration (Kioko et al., 2014) in learning if they are not allowed to invest their identity and cognitive commodity. If the school and home have the different language, both the language environments need to be reshaped with reshaping multilingual scaffolding approach. Then only the kids will be benefitted with the reshaped new multilingual repertoire (Warren, 2017) and children cannot automatically be multilingual but need carefully planned instructional programme (Kitzinger, 2015). Teachers need multilingual education, materials and awareness. Parents need to be aware of their children learning and collaborative to the school for better learning of their kids. We let and encourage our 
kindergarten or elementary level kids for using multimodal semiotics including their home language and transmit their indigenous knowledge system (Njoroge, Mwangi, Ndungu \& Orwenjo, 2014) for communication which could strengthen their learning and make them active learners. Using multilingual pedagogical approach is not free of challenges if it comprises complexity, creativity, elements of entextualisation and resemiotisation (Gynne, 2016) but it is the unavoidable phenomenon in education more in elementary education. Multidimensional collaboration and retrieving striking effort might be the pivotal formula for it.

Language is for facilitation, not for barriers of learning. Because of ideology, power hegemony and lack of multilingual pedagogical awareness we many teachers face challenges and could not educate the children effectively. Here in this case study, the following aspects are discussed.

\section{Multilingual children}

The world is being a global village (McLuhan, 1962) because of technology and communication. Globalization has brought both opportunities and challenges in almost all dimensions of human life. Societies are in dynamic multilingualism. Multilingualism is being continuum of a continuous reshaping phenomenon. It has huge pressure over child educating situation. In the context of Nepal many parents are multilingual and their children are also natural multilingual in urban areas and somewhere in rural areas too. In secondary level or in tertiary level, learners might have low parameter of problem regarding language but in kindergarten or elementary level, there are issues regarding language. Almost all schools of Nepal expose monolingual instruction policy because that is supported by education policy documents, teacher education system at university level, monolingual materials, parents' attitudes, lack of teachers' multilingual pedagogical awareness and socioeconomic psychology/motive of the society/people.

Schools and societies are multilingual but pedagogy, teacher education and materials are still monolingual. There are differences between school multilingualism and social multilingualism because sometimes they do not share common multilingual dimensions, sometimes children have two ethnic languages but none of them is school languages. Here is not only the issue of multilingual education but also the community sharing multilingual education. The school and parents need to develop multilingual education policy in collaboration for children's learning scaffold for the children who get first admission at school. 


\section{Multilingual pedagogy and collaboration}

Since school children are enrolled with multilingual or bilingual historical learning bodies and for multilingual school classes even if they have monolingually biased classes, the children do not have the compartmentalization of their language repertoire. If the learning is as translanguaging and reshaping language knowledge as one nevertheless how many languages a child or speaker uses, why we should not abide the pedagogical strategies based on learning strategies since they are reciprocal.

The school may not do all oneself but needs to collaborate with different agencies because the children come with their socio-cultural body (Darvin \& Norton, 2017). Then only multilingual pedagogy to ensure scaffolding of children's learning can be materialized. The collaborative discussion may plant the acceptance of multilingual teaching learning approach as a new socio-psycho domain in teachers, parents and documented policy making stockholders.

\section{Conclusion}

If a teacher and children do not have the mutual language in classroom instruction and communication, it may tend to germinate problems and challenges for both the teachers and the children as the communication barriers. The children seem unable to impart their basic intention and communication needs in other language rather than in their home language. In this case study, I observed one purposively selected respondent girl's linguistic and other behaviours, and interacted with her teacher, and mother to get in-depth information about her language problem. She belonged to Maithili language community but in her kindergarten she was only exposed to Nepali and English. First she was not able to communicate in Nepali and English languages. After I noticed her problem regarding language, we, including me as an administrator and a researcher, her mother, her teacher, and another secondary level teacher whose home language was also Maithili, were collaboratively able to bring the changes in her communication using English, Nepali and her home language Maithili. An attempt of scaffolding multilingualism for a girl including her home language optimized her learning opportunities and offered her cognitive investment. She seemed to reshape her language repertoire with the multilingual exposure in collaboration even if it was not programmed and planned, only with general sharing, interaction and reshaping of communicative approach as the process of translanguaging with her. 


\section{References}

Bedore, L. M., Peña, E. D., Joyner, D., \& Macken, C. (2011). Parent and teacher rating of bilingual language proficiency and language development concerns. International Journal of Bilingual Education and Bilingualism, 14(5), 489-511. https://doi.org/10.1080/13670050.2010.529102

Creswell, J. W. (2009). Research design: Qualitative, quantitative, and mixed methods approach. (Laureate Education, Inc., custom ed.). Thousand Oaks, CA: Sage Publication.

Darvin, R. \& Norton, B. (2017). Language, identity, and investment in twenty-first century. In Language Policy and Political Isses in Education (pp. 1-15). DOI: 10.1007/978-3-319-02320-5_18-2.

Dornyei, Z. (2007). Research methods in applied linguistics. Oxford: Oxford University Press.

Fairclough, N. (2001). Language and power. Retrieved on 5, December, 2019 from: www.researchgate.net/publication/49551220

Govenment of Nepal. (2015). The Constitution of Nepal. Kathmandu: Nepal Law Book Publication.

Government of Nepal. (1971). Education Act. Kathmandu: Nepal Law Book Publication Committee.

Gynne, A. (2016). Language and social positioning in multilingual school practices studies of Sweden Finnish middle school years. PhD dissertations, Malardalen University Sweden. Sweden: Arkitektkopia, Vasteras. ISSN 1651-4238.

Kandel, B. (2019). Linguistic landscapes in multilingual Nepal: Urban context. Journal of NELTA Gandaki, 2. 12-28. 10.3126/jong.v2i0.26600.

Kioko, A. N., Ndung'u, R. W., Njoroge, M. C., \& Mutiga, J. (2014). Mother tongue and education in Africa: Publicising the reality. Multilingual Education, 4(1), $1-11$.

Kitzinger, A. Ilona. (2015). Mulltilingualism aand mullticultural chllenges in a Hungerian kindergarten. DOI: 10.15774/PPKE.BTK.2015.015.

Koegel, L. K., Koegel, R. L., \& Carter, C. M. (1998). Pivotal responses and the natural language teaching paradigm. In Seminars in Speech and Language, 19 (4), 355-372.

Kramsch, C. (2014). Language and culture. AILA review. 27. 30-55. 10.1075/ aila. $27.02 \mathrm{kra}$.

Lefebvre, E. E. (2012). Student attitude toward multilingual education. Master of Arts Thesis, University of Oregon. https://core.ac.uk/download/ pdf/36687119.pdf 
Lodico, M., Spaulding, D. T., \& Voegtle, K. H. (2010). Methods in educational research. 168 From theory to practice (Laureate Education, Inc., custom ed.). San Francisco, CA: John Wiley \& Sons.

Markowska-Manista, U., Zakrzewska-Olędzka, D., \& Sawicki, K. (2020).

Multilingualism in the Upbringing and education of children in multilingual famiilies: A case study from Poland. Fourth international scientific conference communication trends in the post-literary Era: Multilingualism, Multimodality, multicultralism, KnE social sciences (pp. 64-74). DOI 10.18520/kss.v4i2.6310.

McLuhan, M. (1962). The Gutenberg Galaxy: The making of typographic man. London: Routledge.

Merriam, S. B. (2009). Qualitative research: A guide to design and implementation. San Francisco, CA: Jossey-Bass.

Njoroge, M. C., Mwangi, P. W., Ndungu, R. W., \& Orwenjo, D. O. (2014). Introduction: multilingualism and education: the critical nexus. Multilingual Education a Springer Open Journal. http:/www.multilingual-education.com/ content/4/1/10: May 2020.

Norton, B. (2015). Identity investment, and faces of English internationally. Chinese Journal of Applied Linguaistics, 38 (4). DOI: https://doi.org/10.1515/cjal2015-0025

Saxton, M. (2005). 'Recast' in a new light: Insights for practice from typical language studies. Child Language Teaching \& Therapy - Child Language Teacher, 21, 23-38. 10.1191/0265659005ct279oa.

Ping TAN, C. S. (2015). Interactions in the multilingual classroom: A case study of teacher beliefs and student attitudes L1 use in multilingual classrooms. Master Thesis: Massey University Palmerston North, New Zealand.

Vallejo, C. (2018). Translanguaging: Language, Bilingualism and Education, by Ofelia García and Li Wei. Bellaterra Journal of Teaching \& Learning Language \& Literature, 11, 85. 10.5565/rev/jtl3.764.

Warren, R. A. (2017). Developing multilingual literacies in Sweden and Australia. $\mathrm{PhD}$ thesis, Stockholm University. ISBN 978-91-7649-893-4 access may 26, 2020: http://urn.kb.se/resolve?urn

Yadava, Y. P. (2007). Linguistice deversity in Nepal pperspectives on Language Policy. Constitutioalism and diversity in Nepal. Kathmandu: Center for Nepal and Asia Studies, TU Nepal. 